\title{
PERAN ANGGOTA DEWAN PERWAKILAN DAERAH REPUBLIK INDONESIA DALAM RANGKA MENYERAP ASPIRASI DAERAH ( STUDI KASUS DI PROVINSI JAWA TENGAH )
}

\author{
RATNA HERAWATI
}

\begin{abstract}
ABSTRAK
Adanya reformasi pada tahun 1998 telah melahirkan amandemen terhadap UndangUndang Dasar 1945 sehingga membawa perubahan terhadap sistem ketatanegaraan Indonesia. Salah satunya adalah perubahan pada lembaga legislatif, yaitu hapusnya sistem unikameralisme menjadi sistem bikameralisme. Dengan dianutnya sistem bikameralisme di Indonesia maka muncul Dewan Perwakilan daerah. Dewan Perwakilan Daerah merupakan representasi daerah-daerah yang bertujuan untuk mengakomodasi kepentingan daerah.

Anggota Dewan Perwakilan Daerah dipilih langsung secara perorangan melalui pemilu dengan sistem distrik berwakil banyak. Sebagai alat untuk mengakomodasi kepentingan daerah maka penyerapan aspirasi merupakan kegiatan yang paling penting. Bagaimanakah pelaksanaan peran anggota Dewan Perwakilan Daerah asal Jawa Tengah dalam proses penyerapan aspirasi masyarakat Jawa Tengah, apakah kendala-kendala yang dihadapi anggota Dewan tersebut dan bagaimana upaya untuk meminimalisir kendala tersebut. Oleh karena itu tujuan penelitian ini untuk mengetahui apakah pelaksanaan peran anggota Dewan Pewakilan Daerah asal Jawa Tengah dalam menyerap apirasi daerah sesuai dengan peraturan yang berlaku ataukah tidak.

Spesifikasi penelitian ini adalah deskriptif analitis yang bertujuan untuk memberikan gambaran secara menyeluruh dan mendalam tentang keadaan yang diteliti serta menganalisis mengenai implementasi peran anggota Dewan Perwakilan Daerah asal Jawa Tengah dalam menyerap aspirasi daerah. Metode penelitian dalam tesis ini adalah yuridis empiris sehingga selain menggunakan ketentuan-ketentuan hukum di Indonesia juga menggunakan pendapat para ahli di bidang hukum terutama yang terkait dengan penelitian ini serta kendala yang terjadi atas pelaksanaan peraturan perundang-undangan yang mengatur Dewan Perwakilan Daerah.

Peran anggota Dewan Perwakilan Daerah asal Jawa Tengah untuk dapat menyerap, menghimpun, menampung dan menindaklanjuti aspirasi daerah pada implementasinya belum maksimal. Hal ini dikarenakan adanya kendala-kendala yang meliputi faktor internal dan faktor eksternal. Faktor internal yang dihadapi anggota Dewan Perwakilan Daerah berkaitan dengan lembaga Dewan Perwakilan Daerah sedangkan faktor eksternalnya berkaitan dengan masyarakat/konstituen, DPRD, dan Pemerintah Daerah. Upaya-upaya yang harus dilakukan dalam rangka mengakomodasi kepentingan daerah secara efektif dan adil meliputi faktor internal dan eksternal. Faktor internal untuk meminimalisir kendala tersebut adalah meningkatkan peran anggota Dewan Perwakilan Daerah asal Jawa Tengah sedangkan faktor eksternalnya dengan meningkatkan efektifitas komunikasi dengan
\end{abstract}


masyarakat, DPRD dan Pemerintah Daerah di Jawa Tengah. Oleh karena itu anggota Dewan Perwakilan Daerah asal Jawa Tengah maupun komponen yang ada, meliputi masyarakat, DPRD, dan Pemerintah Daerah, sebaiknya ikut berpartisipasi untuk daat mewujudkan tujuan Dewan Perwakilan Daerah.

Kata kunci: Dewan Perwakilan Daerah, aspirasi daerah

\section{PENDAHULUAN}

\section{a. Latar Belakang}

Reformasi yang terjadi pada tahun 1998 telah melahirkan gagasan untuk melakukan perubahan Undang-Undang Dasar 1945. Dengan adanya amandemen Undang-Undang Dasar 1945 maka terjadi reformasi demokratisasi dan berimplikasi pada struktur formal ketatanegaraan.

Sebagai bagian dari sebuah proses, demokrasi haruslah diperjuangkan melalui penegakan berbagai ketentuan sekaligus operasionalisasi perangkat-perangkatnya agar dapat berperan dalam peningkatan kesejahteraan seluruh rakyat. Melihat hal ini maka reformasi demokrasitisasi memerlukan pelembagaan. Salah satu pelembagaan tersebut adalah lembaga perwakilan. Lembaga perwakilan ini berfungsi sebagai penyalur aspirasi rakyat.

Lembaga perwakilan ini di Indonesia disebut Lembaga Legislatif. Selama ini, Lembaga Legislatif menganut unikameralisme, tetapi dengan sistem ini muncul pergolakan di daerah di mana salah satu sebabnya karena daerah tidak cukup terwakili dalam proses pengambilan keputusan di tingkat pusat. Selain itu aspirasi daerah yang selama ini diwakili melalui Utusan Daerah di MPR dirasakan kurang efektif dalam mengakomodasi aspirasi dan kepentingan daerah. Salah satu faktornya adalah wakil rakyat melalui Utusan Daerah di MPR selalu terafiliasi dengan partai politik tertentu serta tidak sedikit yang bukan berasal dari daerah yang diwakilinya. Demikian juga aspirasi yang disampaikan melalui DPR tidak efektif, karena kepentingan daerah tidak cukup jika hanya diwakili dalam gagasan. Kepentingan daerah perlu diwakili dalam bentuk kehadiran orang daerah. Oleh karena itu muncul pemikiran tentang parlemen bikameral yang bertujuan untuk meningkatkan derajat keterwakilan. 
Dalam rangka mengakomodasi kepentingan daerah secara efektif dan adil dalam rangka pembuatan keputusan politik yang bersifat nasional dan untuk memberdayakan potensi daerah maka diperlukan Dewan Perwakilan Daerah. Dewan Perwakilan Daerah tersebut merupakan representasi daerah-daerah yang dipilih langsung secara perseorangan melalui pemilu dengan sistem distrik berwakil banyak.

Berpijak pada pemikiran di atas, maka anggota DPD berasal dari tiap-tiap provinsi di Indonesia termasuk Provinsi Jawa Tengah. Anggota DPD memiliki peran untuk menjembatani kedua kepentingan kebijakan yaitu berlangsungnya kekuasaan dan kewibawaan pusat di daerah dari satu arah secara top down dan sekaligus pendemokrasian pemerintahan dan akomodasai aspirasi masyarakat daerah secara bottom up.

Sebagai lembaga negara baru, kehadiran Dewan Perwakilan Daerah seharusnya memberikan solusi terhadap sistem politik yang sentralistik. Akan tetapi peran anggota Dewan Perwakilan Daerah tidak dapat maksimal. Selain itu berdasarkan pengamatan selama ini di beberapa daerah di Jawa Tengah, peran yang tidak maksimal tersebut terutama berkaitan dengan penyerapan aspirasi daerah. Mengapa terjadi hal seperti ini dan apa yang menjadi latar belakangnya. Melihat hal-hal tersebut di atas mendorong peneliti untuk mengkaji mengenai "Peran Anggota Dewan Perwakilan Daerah Republik Indonesia dalam Rangka Menyerap Aspirasi Daerah (Studi Kasus di Provinsi Jawa Tengah )".

\section{b. Permasalahan}

1. Bagaimanakah pelaksanaan peran anggota Dewan Perwakilan Daerah Republik Indonesia asal Provinsi Jawa Tengah dalam rangka menyerap aspirasi daerah?

2. Bagaimanakah tata cara penyerapan aspirasi masyarakat Jawa Tengah oleh anggota Dewan Perwakilan Daerah asal Jawa Tengah?

3. Kendala-kendala apasajakah yang muncul dan bagaimanakah upaya untuk meminimalisir kendala-kendala tersebut sehingga dapat meningkatkan peran Dewan Perwakilan Daerah dalam rangka menyerap aspirasi daerah?

\section{c. Tujuan dan Kontribusi Penelitian}

Tujuan penelitian yaitu 
a. untuk mengetahui dan menelaah peran anggota Dewan Perwakilan Daerah asal Provinsi Jawa Tengah dalam menyerap aspirasi daerah dan pelaksanaannya di Provinsi Jawa Tengah;

b. untuk mengetahui tata cara penyerapan aspirasi masyarakat Jawa Tengah oleh anggota Dewan Perwakilan Daerah asal Jawa Tengah; dan

c. untuk mengidentifikasikan faktor-faktor yang melatarbelakangi munculnya persoalanpersoalan dalam pelaksanaan peran anggota Dewan Perwakilan Daerah asal Provinsi Jawa Tengah serta memberikan alternatif pemikiran upaya-upaya untuk mengatasi hambatan-hambatan tersebut sehingga dapat meningkatkan peran anggota Dewan Perwakilan Daerah asal Provinsi Jawa Tengah dalam rangka menyerapa spirasi daerah.

Sedangkan kontribusi penelitian ini:

1. secara praktis yaitu dapat bermanfaat bagi pihak-pihak yang membutuhkan informasi mengenai peran anggota Dewan Perwakilan Daerah asal Provinsi Jawa Tengah dalam rangka menyerap aspirasi daerah, dan dapat memberi masukan bagi anggota Dewan Perwakilan Daerah asal Provinsi Jawa Tengah sesuai batas-batas perannya sehingga anggota Dewan Perwakilan Daerah tersebut dapat lebih waspada dan bertanggungjawab; dan

2. secara teotitis yaitu dapat menambah wawasan tentang peran anggota Dewan Perwakilan Daerah asal Provinsi Jawa Tengah dalam rangka menyerap aspirasi daerah dan pelaksanannya di Provinsi Jawa Tengah sehingga dapat berguna bagi pengembangan Ilmu Hukum Tata Negara.

\section{d. Tinjauan Pustaka}

\section{Latar Belakang Berdirinya Dewan Perwakilan Daerah}

Keberadaan Dewan Perwakilan Daerah Republik Indonesia (selanjutnya disebut DPD RI) tidak terlepas dari berbagai latar belakang persoalan-persoalan lembaga-lembaga negara di Indonesia. Adanya persoalan-persoalan pada lembaga-lembaga negara ini dimaksudkan agar nantinya mendapatkan sistem kelembagaan politik yang sesuai dengan kondisi masyarakat Indonesia. Oleh karena itu ada beberapa faktor yang menjadi latar belakang berdirinya DPD RI.

\section{Filosofis}


Aristoteles menegaskan bahwa negara semestinya memiliki tujuan yang tertinggi, paling mulia, dan terluhur dibanding persekutuan hidup lainnya. Menurut Aristoteles yang dikutip oleh Theo Huijbers bahwa negara haruslah senantiasa mengupayakan kebaikan tertinggi yang semaksimal mungkin bagi para warganya. Kebaikan yang semaksimal mungkin dapat berarti kehidupan yang aman, tenteram dan sejahtera. ${ }^{1}$

\section{Historis}

Lembaga perwakilan dipengaruhi oleh sejarah suatu bangsa sehingga melatarbelakangi pembentukan lembaga perwakilan tersebut, termasuk di Indonesia. Hal ini dikemukakan oleh Hasyim Asy'ari.

Keberadaan lembaga perwakilan rakyat tidak lepas dari aspek historis suatu bangsa. Demikian juga sistem perwakilan yang dianut juga sangat dipengaruhi oleh kondisi sosial politik yang melatarbelakangi pembentukan lembaga perwakilan rakyat tersebut. ${ }^{2}$

Berdasarkan sejarahnya, lembaga perwakilan daerah di Indonesia sebenarnya telah ada sejak sebelum kemerdekaan. Lembaga perwakilan tersebut mengalami berbagai persoalan. Salah satunya berdasarkan pendapat Tambunan. "Persoalaan utama yang ada pada lembaga tersebut adalah tidak pernah hadirnya lembaga perwakilan daerah yang mampu menyuarakan kepentingan-kepentingan daerah di tingkat nasional."”3

\section{Yuridis}

Adanya lembaga negara tersebut berawal dengan adanya teori kedaulatan rakyat. Teori kedaulatan rakyat oleh negara selalu mencerminkannya dalam konstitusikonstitusinya yang mengatur secara garis besar di antara kedaulatan rakyat dan berupa kemauan umum dengan kegiatan kelembagaan negara yang berhubungan dengan kedaulatan tersebut. Salah satu pendapat mengenai hal tersebut dikemukakan oleh S.M Amin. "Apabila di dalam suatu negara terdapat adanya lembaga-lembaga negara yang memiliki kekuasaan tertentu maka kedaulatan mempunyai hubungan yang erat dengan lembaga-lembaga tersebut."4

\footnotetext{
${ }^{1}$ Theo Huijbers, Filsafat Hukum, (Yogyakarta: Kanisius, 1995), hal113.

${ }^{2}$ Hasyim Asy'ari, Kedudukan dan Peran DPD dalam Sistem Ketatanegaraan Indonesia, Makalah dalam Semiloka "Optimalisasi Fungsi dan Kedudukan DPD RI secara Kelembagaan", diselenggarakan di Semarang, 12 Januari 2006.

3 ASS Tambunan, MPR Perkembangan dan Pertumbuhan: Suatu Pengamatan dan Analisis, (Jakarta: Sinar Harapan, 1991), hal 46.

${ }^{4}$ S.M. Amin, Demokrasi Selayang Pandang, (Jakarta: Pradnya Paramita, 1976), hal 33.
} 
Teori kedaulatan rakyat mempunyai pengaruh yang sangat kuat sehingga melahirkan adanya demokrasi. Dengan adanya demokrasi maka suatu negara harus mempunyai lembaga perwakilan dalam struktur ketatanegaraan. Oleh karena itu teori kedaulatan rakyat dianut oleh Indonesia sebagaimana terkandung dalam Undang-Undang Dasar Negara Republik Indonesia Tahun 1945 alenia IV dimana Indonesia adalah Negara Republik yang Berkedaulatan Rakyat.

Implementasi atas konstitusi adalah lahirnya peraturan tata tertib DPD RI. Penyusunan peraturan tata tertib DPD oleh MPR dimaksudkan agar DPD sebagai lembaga baru di awal masa jabatannya dapat melaksanakan persidangan dengan tertib dan lancar.

\section{Dasar Hukum Pembentukan Dewan Perwakilan Daerah}

Peraturan yang menjadi dasar hukum adanya DPD yaitu UUD Negara RI tahun 1945 Pasal 22C dan Pasal 22D, Ketetapan MPR No. IX/MPR/2000 Undang-Undang Nomor 22 Tahun 2003, Undang-Undang Nomor 10 Tahun 2004, Peraturan Presiden RI Nomor 51 Tahun 2005, Peraturan Tata Tertib Dewan Perwakilan Daerah Republik Indonesia Tahun 2005 yaitu Keputusan DPD RI Nomor 2 Tahun 2004 yang diubah dengan Keputusan DPD Nomor 29 Tahun 2005, dan Keputusan DPD RI Nomor 1 tahun 2005.

\section{Gambaran Umum Dewan Perwakilan Daerah}

Dalam rangka mengakomodasikan kepentingan daerah secara efektif dan adil dalam rangka pembuatan keputusan politik yang bersifat nasional dan untuk memberdayakan potensi daerah, dibutuhkan sebuah lembaga. Lembaga ini mempunyai kewenangankewenangan tertentu. Salah satu pendapat mengenai hal tersebut dikemukakan oleh Saafroedin Bahar. "Untuk menjaga integrasi bangsa maka diperlukan suatu lembaga yang dapat memberikan masukan, pertimbangan dan bahkan pengawasan terbatas." ${ }^{\circ}$ Oleh karena itu muncul DPD.

DPD merupakan lembaga perwakilan daerah yang berkedudukan sebagai lembaga negara. Adapun kedudukan DPD sebagai lembaga negara ditentukan dalam Pasal 40 UU No. 20 tahun 2003 tentang Susunan dan Kedudukan MPR, DPR, DPD dan DPRD (selanjutnya disebut UU Susduk). DPD ini adalah lembaga negara baru yang berfungsi memperjuangkan aspirasi daerah dan kepentingan daerah.

\footnotetext{
5 Saafroedin Bahar dan A.B Tangadililing, Integrasi Nasional: Teori, Masalah dan Strategi, (Jakarta: Ghalia Indonesia, 1999), hal 59.
} 
Adapun dasar pertimbangan teoritis kehadiran DPD RI antara lain untuk membangun sebuah mekanisme kontrol dan keseimbangan (checks and balances) antar cabang kekuasaan negara dalam lembaga legislatif itu sendiri. Selain itu DPD RI diharapkan mampu menjamin dan menampung perwakilan kepentingan daerah-daerah secara memadai serta memperjuangkan aspirasi dan kepentingan daerah dalam lembaga legislatif.

Sedangkan dasar pertimbangan politis kehadiran DPD RI adalah memperkuat ikatan daerah-daerah dalam wadah Negara Kesatuan Republik Indonesia; meneguhkan persatuan dan semangat kebangsaan seluruh daerah dalam forum yang mempertemukan berbagai latar belakang persoalan kedaerahan; meningkatkan aspirasi dan kepentingan daerah-daerah dalam perumusan kebijakan nasional; serta mendorong percepatan demokrasi, pembangunan dan kemajuan daerah secara berkeadilan, kesetaraan dan berkesinambungan.

Berdasarkan Pasal 4 Peraturan Tata Tertib DPD RI bahwa DPD melakukan tugasnya berlandaskan Pancasila dan UUD Negara RI Tahun 1945. Sedangkan fungsi DPD seperti yang tercantum dalam Pasal 5 peraturan yang sama yaitu pengajuan usul, ikut dalam pembahasan dan memberikan pertimbangan yang berkaitan dengan bidang legislasi tertentu; dan pengawasan atas pelaksanaan undang-undang tertentu.

Mengenai kewenangan DPD, Pasal 22D UUD 1945 menetapkan: (1) DPD dapat mengajukan kepada DPR rancangan UU yang berkaitan dengan otonomi daerah, hubungan pusat dan daerah, pembentukan dan pemekaran serta penggabungan daerah, pengelolaan sumber daya alam dan sumber daya ekonomi lainnya serta yang berkaitan dengan perimbangan keuangan pusat dan daerah; (2) DPD ikut membahas rancangan UU yang berkaitan dengan otonomi daerah, hubungan pusat dan daerah, pembentukan dan pemekaran serta penggabungan daerah, pengelolaan sumber daya alam dan sumber daya ekonomi lainnya serta yang berkaitan dengan perimbangan keuangan pusat dan daerah serta DPD dapat meberikan pertimbangan kepada DPR atas RUU APBN dan RUU yang berkaitan dengan pajak, pendidikan dan agama; dan (3) DPD melakukan pengawasan terhadap pelaksanaan undang-undang mengenai otonomi daerah, hubungan pusat dan daerah, pembentukan dan pemekaran serta penggabungan daerah, pengelolaan sumber daya alam dan sumber daya ekonomi lainnya pelaksanaan APBN, pajak, pendidikan dan agama serta meyampaikan hasil pengawasannya kepada DPR sebagai bahan pertimbangan untuk 
ditindaklanjuti. Selain tugas dan wewenang pokok tersebut, DPD juga memiliki kewenangan memberikan pertimbangan kepada DPR untuk pengisian jabatan strategis kenegaraan, yaitu dalam memilih anggota Badan Pemeriksa Keuangan (Pasal 45 ayat(1) UU Susduk). Sedangkan dalam masalah keuangan negara berdasarkan Pasal 44 ayat(1) dan Pasal 47 UU Susduk, DPD memiliki kewenangan: (1) memberikan pertimbangan kepada DPR atas rancangan undang-undang APBN dan rancangan undang-undang yang berkaitan dengan pajak, pendidikan, dan agama, dan (2) menerima hasil pemeriksaan keuangan negara dari BPK untuk dijadikan bahan pertimbangan bagi DPR tentang rancangan undangundang yang berkaitan dengan APBN.

Untuk mendukung kelancaran pelaksanaan tugas Dewan Perwakilan Daerah maka dibentuk Sekretariat Jenderal. Sekretariat Jenderal ini diatur dalam Peraturan Presiden RI Nomor 51 Tahun 2005. Kesekretariatan ini berlokasi di sekitar Gedung MPR/DPR Senayan. Gedung Dewan Perwakilan Daerah berlantai empat, diresmikan pada tanggal 16 September 2004 oleh H Amien Rais bersama para Pimpinan MPR Periode 1999-2004.

\section{Peran Anggota Dewan Perwakilan Daerah}

Yang dimaksud peran anggota Dewan Perwakilan Daerah berkaitan dengan fungsi. Jika merujuk pada asal-usul katanya, istilah fungsi berasal dari Bahasa Inggris function yang artinya jenis tindakan atau kegiatan yang sesuai bagi orang atau sesuatu, atau tujuan untuk apa sesuatu dibuat. Sedangkan menurut Kamus Bahasa Indonesia, fungsi berarti jabatan/pekerjaan yang dilakukan atau kegunaan suatu hal. Oleh karena itu dalam pengertian fungsi terkandung wewenang dan tugas.

Fungsi, tugas, dan wewenang DPD RI diatur dalam UUD Negara RI Tahun 1945 Pasal 22D ayat (1), (2) dan (3). Selain itu Fungsi, tugas, dan wewenang DPD RI tercantum dalam UU Susduk MPR, DPR, DPD, dan DPRD Pasal 41 sampai 47. Fungsi, tugas, dan wewenang DPD RI juga diatur dalam Peraturan Tata Tertib DPD RI Tahun 2005 Pasal 5 dan Pasal 6.

\section{Anggota Dewan Perwakilan Daerah}

Sistem distrik berwakil banyak dipakai dalam pemilihan anggota DPD RI pemilu tahun 2004. Sistem distrik berwakil banyak artinya satu distrik pemilihan atau provinsi akan memilih wakil lebih dari satu orang. Mereka yang meraih suara terbanyak yang berhak menjadi anggota DPD RI. Apabila ada beberapa calon memproleh suara yang sama 
maka calon dengan penyebaran perolehan suara yang lebih merata menjadi pemenang atau ditetapkan sebagai calon terpilih.

Dewan Perwakilan Daerah terdiri atas wakil-wakil daerah provinsi yang dipilih melalui pemilihan umum. Anggota DPD dari setiap provinsi ditetapkan sebanyak empat orang. Jumlah seluruh Anggota DPD tidak lebih dari 1/3 jumlah anggota DPR. Keanggotaan DPD diatur dalam Pasal 22C UUD Negara RI Tahun 1945 ayat (1) Anggota DPD dipilih dari setiap provinsi melalui pemilu dan pemilu untuk memilih anggota DPD dilakukan secara individu bukan atas nama partai; (2) Anggota DPD dari setiap provinsi jumlahnya sama dan jumlah seluruh anggota DPD tidak lebih dari sepertiga jumlah anggota DPR; (3) Susunan dan kedudukan DPD diatur dengan undang-undang(UU). Adapun proses pemberhentian anggota DPD diatur dalam Pasal 22D ayat (4) UUD 1945 dimana syaratsyarat dan tata caranya diatur dalam UU.

Selain diatur dalam UUD Negara RI Tahun 1945, keanggotaan DPD juga tercantum dalam UU Susduk MPR, DPR, DPD, dan DPRD. Keanggotaan DPD dalam UU Susduk tersebut diatur dalam Pasal 33 sampai 36 dan Pasal 49 mengenai hak anggota DPD serta Pasal 50 mengenai kewajiban anggota DPD.

Ada syarat-syarat yang harus dipenuhi untuk dapat dipilih menjadi anggota DPD. Persyaratan tersebut dikelompokkan dalam persyaratan yang bersifat umum dan khusus. Menurut Sri Soemantri Martosoewignjo,"Persyaratan umum adalah persyaratan yang biasanya tercantum dalam penentuan keanggotaan dalam sebuah lembaga negara, seperti yang berkenaan dengan kewarganegaraan, usia seorang anggota, dan pendidikan. Sedangkan persyaratan khusus adalah syarat-syarat yang berlaku hanya bagi mereka yang dicalonkan." ${ }^{, 6}$ Persyaratan umum untuk menjadi calon anggota DPD tercantum dalam Pasal 60 UU Susduk sedangkan persyaratan khususnya tercantum dalam Pasal 63 UU yang sama.

Berdasarkan Keputusan DPD RI Nomor 29/DPD/2005 tentang Peraturan Tata Tertib DPD RI pada Bab I Pasal 1 butir 10, anggota DPD, yang selanjutnya disebut Anggota adalah wakil daerah provinsi yang telah bersumpah atau berjanji sesuai dengan peraturan perundang-undangan dan dalam melaksanakan tugasnya memperhatikan aspirasi masyarakat dan daerah dalam kerangka Negara Kesatuan Republik Indonesia. Dalam

\footnotetext{
${ }^{6}$ Sri Soemantri Martosoewignjo, Susunan dan Kedudukan Dewan Perwakilan Daerah, dari internet DPD.
} 
keputusan tersebut mengenai keanggotaan diatur dalam Bab II bagian pertama Pasal 7 hingga Pasal 11 serta Bab IV bagian kedua Pasal 14 dan 15.

Dalam Pasal 33 ayat (4) Undang-Undang Republik Indonesia Nomor 22 Tahun 2003 mengatur bahwa anggota DPD berdomisili di daerah pemilihannya dan selama bersidang bertempat tinggal di ibukota negara Republik Indonesia. Berdasarkan Pasal tersebut maka Jawa Tengah sebagai salah satu provinsi di Indonesia mempunyai anggota di dalam Dewan Perwakilan Daerah.

Masa jabatan anggota DPD adalah lima tahun dan berakhir bersama pada saat Anggota DPD yang baru mengucapkan sumpah/janji. Anggota DPD sebelum memangku jabatannya mengucapkan sumpah/janji secara bersama-sama yang dipandu oleh Ketua Mahkamah Agung dalam Sidang Paripurna DPD.

Anggota DPD mempunyai hak menyampaikan usul dan pendapat, memilih dan dipilih, membela diri, imunitas, protokoler; dan keuangan dan administratif. Selain itu anggota DPD mempunyai kewajiban mengamalkan Pancasila; melaksanakan UndangUndang Dasar Negara Republik Indonesia Tahun 1945 dan menaati segala peraturan dan perundang-undangan; melaksanakan kehidupan demokrasi dalam penyelenggaraan pemerintahan; mempertahankan dan memelihara kerukunan nasional dan keuntungan negara Republik Indonesia; memperhatikan upaya peningkatkan kesejahteraan rakyat; menyerap, menghimpun, menampung dan menindaklanjuti aspirasi masyarakat dan daerah; mendahulukan kepentingan negara di atas kepentingan pribadi, kelompok dan golongan; memberikan pertanggungjawaban secara moral danpolitis kepada pemilih dan daerahnya pemilihannya; menaati kode etik dan Peraturan Tata Tertib DPD; dan menjaga etika dan norma adat daerah yang diwakilinya. Pelaksanaan ketentuan di atas diatur dalam Peraturan Tata Tertib DPD.

Salah satu alat kelengkapan DPD adalah Panitia Ad Hoc. Mengenai Panitia Ad Hoc diatur dalam Bab VI Peraturan Tata Tertib DPD RI. Keangotaan Panitia Ad hoc ditetapkan oleh Sidang Paripurna DPD pada permulaan masa keanggotaan DPD dan pada setiap permulaan tahun sidang, kecuali pada permulaan tahun sidang terakhir dari masa keangotaan DPD. Setiap anggota DPD harus menjadi anggota salah satu Panitia Ad Hoc kecuali Pimpinan DPD dan Pimpinan MPR unsur DPD. Begitupula anggota Dewan Perwakilan Daerah Republik Indonesia asal Provinsi Jawa Tengah. Panitia Ad hoc terbagi 
menjadi 4 bagian yang masing-masing mempunyai tugasnya sendiri-sendiri. Ruang lingkup Panitia Ad Hoc I yaitu otonomi daerah, hubungan pusat dan daerah serta pembentukan, pemekaran dan penggabungan daerah. Panitia Ad hoc II ruang lingkupnya meliputi pengelolaan sumberdaya alam dan pengelolaan sumber daya ekonomi lainnya sedangkan Panitia Ad Hoc III meliputi pendidikan dan agama. Ruang lingkup Panitia Ad Hoc IV mengenai rancangan anggaran pendapatan dan belanja negara, perimbangan keuanagn pusat dan daerah, memberikan pertimbangan hasil pemeriksaan keuangan negara dan pemilihan anggota BPK, dan pajak.

Pembagian tugas anggota Dewan Perwakilan Daerah Republik Indonesia asal Provinsi Jawa Tengah yaitu Dra. Hj. Nafisah, SM sebagai anggota Panitia Ad Hoc III, Ir. H. Budi Santosa sebagai anggota Panitia Ad Hoc II, Drs. H. Sudharto, M.A. sebagai anggota Panitia Ad Hoc I, dan K.H. Ahmad Chalwani sebagai anggota Panitia Ad Hoc IV. Penggantian anggota Panitia Ad Hoc berdasarkan permusyawaratan anggota dari Provinsi yang bersangkutan dan diusulkan kepada Pimpinan DPD.

\section{Penyerapan Aspirasi Daerah}

Salah satu kewajiban anggota DPD adalah menyerap, menghimpun, menampung dan menindaklanjuti aspirasi masyarakat dan daerah. Sebagai alat untuk mengakomodasi kepentingan daerah maka penyerapan aspirasi merupakan kegiatan anggota DPD RI yang paling penting. Dalam operasionalisasi pelaksanaannya, penyerapan aspirasi masyarakat ini dapat dilakukan dalam dua bentuk yaitu secara langsung dan tidak langsung.

Aspirasi masyarakat dari setiap daerah ini biasanya sangat beragam. Dari keberagaman inilah para wakil rakyat dapat melihat kebutuhan-kebutuhan yang sinergis. Sinergisitas ini bukan saja antar daerah tetapi juga provinsi dan pusat. Oleh sebab itu keberagaman inilah yang dijadikan pokok penentu sebuah kebijakan.

Telah di sebutkan di atas bahwa salah satu tujuan adanya DPD sebagai penghuni parlemen bikameral adalah dapat mengakomodasi kepentingan rakyat daerah. Untuk mewujudkan tujuan tersebut maka penyelenggaraan pemerintahan melalui asas desentralisasi.

Desentralisasi pada dasarnya terjadi setelah sentralisasi melalui asas dekonsentrasi tidak dapat melaksanakan tugas pemerintahan secara baik dalam arti pemerintahan gagal dalam mewujudkan pemerintahan yang demokratis. Asas ini berpijak pada pemerintahan 
yang mampu mengakomodsikan unsur-unsur yang bersifat kedaerahan berdasarkan aspirasi masyarakat daerah. ${ }^{7}$

\section{e. Metode Penelitian}

Metode yang digunakan dalam penelitian ini adalah yuridis empiris, dalam penelitian ini selain menggunakan ketentuan-ketentuan hukum yang berlaku di Indonesia juga menggunakan pendapat para ahli di bidang hukum tertentu terutama yang terkait dengan penelitian ini, serta kendala yang terjadi atas pelaksanan peraturan perundang-undangan yang mengatur Dewan Perwakilan Daerah. Spesifikasi penelitian yang dipergunakan dalam penelitian ini adalah deskripitif analitis karena bertujuan memberikan gambaran secara menyeluruh dan mendalam tentang suatu keadaan atau gejala yang diteliti serta menganalisa mengenai implementasi peran anggota Dewan Perwakilan Daerah asal Jawa Tengah dalam menyerap aspirasi daerah. Data yang dipergunakan dalam penelitian ini adalah jenis data primer dan data sekunder. Data primer yang dipergunakan bersumber atau diperoleh dari penelitian lapangan. Sedangkan data sekunder berupa data yang bersumber atau diperoleh dari penelitian kepustakaan. Pengumpulan data dalam penelitian ini dilakukan dengan cara studi pustaka dan wawancara. Penelitian ini menggunakan metode analisis kualitatif.

\section{HASIL PENELITIAN DAN ANALISIS}

\section{Pelaksanaan Peran Anggota Dewan Perwakilan Daerah asal Jawa Tengah}

Pelaksanaan peran anggota Dewan Perwakilan Daerah asal Jawa Tengah untuk dapat menyerap, menghimpun, menampung dan menindaklanjuti aspirasi daerah pada implementasinya belum maksimal. Hal ini dikarenakan adanya kendala yang dihadapi. Pelaksanaan peran anggota Dewan Perwakilan Daerah Republik Indonesia (DPD RI) asal Jawa Tengah berkaitan dengan pembagian tugas masing-masing anggota. Pembagian tugas masing-masing anggota berkaitan dengan salah satu alat kelengkapan DPD yaitu Panitia Ad Hoc (PAH).

Berdasarkan fungsi DPD RI maka tugas PAH meliputi bidang pengajuan rancangan undang-undang (RUU), bidang pembahasan RUU, bidang pertimbangan, dan bidang pengawasan. Dalam mengajukan RUU meliputi persiapan, pembahasan, dan

\footnotetext{
7 Titik Triwulan Titik, Pokok-Pokok Hukum Tata Negara Indonesia, (Jakarta: Prestasi Pustaka, 2006), hal 185.
} 
penyempurnaan rancangan undang-undang tertentu. Berkaitan dengan tugas PAH di bidang pengajuan rancangan undang-undang maka memerlukan alat kelengkapan DPD yaitu Panitia Perancang Undang-Undang. Panitia Ad Hoc dalam melaksanakan tugas tersebut dapat mengadakan rapat konsultasi dengan alat kelengkapan DPR; mengadakan rapat kerja dengan DPR, pemerintah, pemerintah daerah, dan DPRD; mengadakan rapat dengar pendapat dan rapat dengar pendapat umum; mengadakan rapat gabungan PAH; mengadakan kunjungan kerja; dan mengadakan studi banding atas persetujuan Pimpinan DPD.

Salah satu pelaksanaan peran anggota DPD RI asal Jawa Tengah dengan kunjungan kerja yang telah dilakukan pada tahun sidang 2004 - 2005 dan pada tahun sidang 20052006 (terbagi menjadi dua tahap). Tahap pertama kunjungan kerja tanggal 22 September sampai 31 Oktober 2006 dan tahap kedua kunjungan kerja yang dilaksanakan pada tanggal 8 Desember 2006 sampai 7 Januari 2007.

Langkah selanjutnya adalah pembuatan Keputusan yang melalui tiga tingkat pembicaraan: Tingkat I pembahasan oleh Sidang Parpurna DPD terhadap berbagai masalah yang berkaitan dengan tugas dan wewenang DPD. Tingkat II pembahasan oleh Alat Kelengkapan DPD terhadap hasil pembicaraan Tingkat I dengan kegiatan penyampaian pandangan dan pendapat anggota rapat/sidang terhadap materi yang ditugasi oleh Sidang Paripurna untuk dibahas lebih lanjut, penyusunan daftar inventarisasi masalah berdasarkan bahan-bahan yang masuk, pembahasan materi berdasarkan daftar inventarisasi masalah, penyusunan materi rancangan keputusan DPD sebagai bahan untuk dilaporkan dan diambil keputusan dalam pembicaraan Tingkat III. Alat kelengkapan DPD dapat didampingi oleh Pakar/Ahli/Tim Asistensi. Tingkat III pengambilan keputusan oleh Sidang Paripurna DPD.

Setelah itu melakukan proses penyusunan dan pembahasan Rancangan UndangUndang dari DPD yang dilakukan melalui dua tingkat pembicaraan: Tingkat I dalam Rapat PAH, Rapat Gabungan PAH, Rapat Panitia Perancang Undang-Undang dan/atau Rapat Panitia Khusus dengan kegiatan: inventarisasi materi, dilakukan dalam bentuk penyerapan aspirasi masyarakat dan/atau daerah, Rapat Kerja, Rapat Dengar Pendapat, dan Rapat Dengar Pendapat Umum serta pandangan dan pendapat dari anggota; penyusunan dan pembahasan Daftar Inventarisasi Masalah; penyusunan dan pembahasan naskah akademik dan RUU berdasarkan inventarisasi materi dan Daftar Inventarisasi Masalah; uji sahih, 
dilakukan dalam bentuk Rapat Kerja, Rapat Dengar Pendapat, Rapat Dengar Pendapat Umum, dan telaahan sejawat (peer review); dan harmonisasi, pembulatan, dan pemantapan konsepsi RUU. Tingkat II dalam Sidang Paripurna dimana pengambilan keputusan oleh Sidang Paripurna DPD yang didahului oleh laporan Alat Kelengkapan DPD mengenai hasil pembicaraan Tingkat I. Selambat-lambatnya 5 hari kerja sejak usul RUU disahkan menjadi RUU maka RUU beserta penjelasan/keterangan dan/atau naskah akademis disampaikan secara tertulis kepada Pimpinan DPR dengan surat pengantar dari Pimpinan DPD. Surat pengantar tersebut menyebutkan alat kelengkapan yang mewakili DPD dalam melakukan pembahasan RUU. Rancangan Undang-Undang tersebut disampaikan juga kepada Presiden. Setelah itu, DPD melakukan pembahasan usul RUU bersama DPR atas undanagn DPR. Dalam hal ini DPD diwakili oleh Panitia Perancang Undang-Undang dan/atau PAH yang membidangi materi muatan RUU yang akan dibahas. Hasil pembahasan ini merupakan usul RUU dari DPD sebagai bahan pembahsan DPR dengan Pemerintah. Pada saat pembahasan RUU antara DPR dengan Pemerintah, DPD diundang untuk menyampaikan pendapat dan pandangannya mengenai RUU yang diusulkannya pada awal pembicaraan tingkat I sesuai dengan Peraturan Tata Tertib DPR. Dalam pembahasan RUU di DPR, alat kelengkapan yang ditugasi wajib menyampaikan laporan perkembangan pembahasan RUU secara berkala kepada seluruh anggota dan Pimpinan DPD. Apabila dalam pembahasan ada masalah yang sifatnya prinsipil dan akan mengubah isi serta arah RUU, alat kelengkapan DPD yang ditugasi dapat meminta Pimpinan DPD untuk membahasnya dalam Sidang Paripurna yang khusus untuk itu. Pembahasan dalam Sidang Paripurna terlebih dahulu mendengarkan laporan dari alat kelengkapan yang ditugasi dengan disertai saran pemecahan yang diperlukan untuk memperoleh keputusan. Sedangkan pengajuan dan pembahasan Rancangan Undang-Undang yang berasal dari DPR atau Pemerintah juga melalui beberapa tahap. Setelah RUU yang berasal dari DPR atau Pemerintah diterima oleh Pimpinan DPD, dalam Sidang Paripurna DPD berikutnya, Pimpinan sidang memberitahukan kepada anggota tentang masuknya RUU tersebut, kemudian membagikan kepada seluruh anggota. Kemudian DPD menugasi Panitia Ad Hoc/Panitia Perancang Undang-Undang untuk membahas dan/atau menyempurnakan RUU sebagai bahan dalam pembahasan bersama DPR dan Pemerintah. Panitia Ad Hoc/Panitia Perancang Undang-Undang menyampaikan laporan pelaksanaan tugas kepada Sidang 
Paripurna DPD selambat-lambatnya 30 hari kerja sejak ditugasi oleh Sidang Paripurna DPD. DPD yang diwakili oleh Panitia Ad Hoc/Panitia Perancang undang-Undang, atas undangan DPR ikut melakukan pembahasan RUU tersebut bersama DPR dan Pemerintah pada awal pembicaraan Tingkat I sesuai Peraturan Tata Tertib DPR. Apabila DPR dan/atau Pemerintah menolak masukan yang disampaikan DPD dalam pembahasan tersebut maka DPD meminta penjelasan kepada DPR dan/atau Pemerintah. Kemudian Pimpinan DPD menerima penjelasan secara tertulis dari Pimpinan DPR dan/atau Pemerintah. Penjelasan tersebut oleh Pimpinan DPD disampaikan kepada seluruh anggota. Setelah itu, DPD meyampaikan jawaban atas penjelasan DPR.

\section{Tata Cara Penyerapan Aspirasi Masyarakat Jawa Tengah}

Salah satu kegiatan anggota DPD RI yaitu menyerap, menghimpun, menampung dan menindaklanjuti aspirasi masyarakat dan daerah yang berada dalam ruang lingkup tugas dan wewenang DPD. Penyerapan aspirasi daerah dilakukan dalam dua bentuk yaitu secara langsung dan tidak langsung.

Berikut ini tahapan-tahapannya: (1)Panitia Ad Hoc, anggota, atau pengelompokan anggota yang dibentuk oleh DPD menindaklanjuti aspirasi masyarakat dan daerah. Pimpinan DPD menerima dan menyalurkan aspirasi masyarakat dan daerah kepada alat kelengkapan DPD sesuai dengan ruang lingkup tugas dan wewenangnya atau Perwakilan Provinsi yang bersangkutan yang difasilitasi oleh Sekretariat Jenderal. Pada saat anggota melakukan kunjungan kerja dan kegiatan di daerah yang diwakilinya, Sekretariat Jenderal berkoordinasi dengan Sekretariat Daerah dan Sekretariat DPRD menerima dan menyalurkan aspirasi masyarakat dan daerah kepada anggota; (2)Wakil daerah menyusun laporan hasil kunjungan kerja dalam bentuk resume aspirasi masyarakat yang telah dipisahkan berdasarkan persoalan masing-masing, melakukan identifikasi persoalanpersoalan tersebut sehingga menjadi jelas dan spesifik dan melakukan pemilihan atau kategorisasi berdasarkan tugas, kewenangan lembaga legislatif dan eksekutif, seperti : persoalan yang menjadi kewenangan DPD RI sendiri, persoalan yang menjadi kewenangan DPRD dan Pemda Provinsi, persoalan yang menjadi kewenangan DPRD kabupaten/kota, atau Pemda kabupaten/kota dan persoalan yang di luar kewenangan DPD RI selanjutnya disampaikan melalui mekanisme rapat kerja di daerah yang didasarkan atas skala prioritas persoalan; (3) Persoalan yang menjadi kewenangan DPD RI kemudian dibawa ke Pusat 
untuk disusun bersama-sama anggota DPD RI provinsi masing-masing dan dipilah berdasarkan wilayah kerja PAH untuk diparipurnakan. Laporan yang disampaikan pada paripurna setiap awal masa sidang kemudian disalurkan kepada PAH berdasarkan wilayah kerja masing-masing untuk dibahas bersama dengan pemerintah, dalam hal ini menteri terkait; (4)Terkait dengan masukan dari berbagai kalangan masyarakat mengenai peran ideal DPD ke depan dan peningkatan peran DPD RI dalam menjembatani hubungan antara Pemerintah Pusat dan Daerah yang konstruktif dan sinergis, maka Kelompok DPD di MPR akan menyampaikan masukan tersebut kepada Pimpinan MPR RI untuk dapat diproses lebih lanjut.

\section{Kendala-kendala dan Upaya Meminimalisir Kendala-kendala Tersebut}

Kendala-kendala yang dihadapi untuk meningkatkan peran anggota Dewan Perwakilan Daerah asal Jawa Tengah dalam rangka menyerap aspirasi daerah meliputi faktor internal dan faktor eksternal. Faktor internal yang dihadapi berkaitan dengan lembaga Dewan Perwakilan Daerah sedangkan faktor eksternalnya berkaitan dengan masyarakat/konstituen, DPRD, dan Pemerintah Daerah. Upaya yang harus dilakukan dalam rangka mengakomodasi kepentingan daerah meliputi faktor internal dan eksternal. Faktor internal untuk meminimalisir kendala tersebut adalah meningkatkan peran anggota Dewan Perwakilan Daerah asal Jawa Tengah sedangkan faktor eksternalnya dengan meningkatkan efektifitas komunikasi dengan masyarakat, DPRD dan Pemerintah Daerah di Jawa Tengah.

\section{PENUTUP}

\section{Kesimpulan}

1. Pelaksanaan peran anggota Dewan Perwakilan Daerah asal Jawa Tengah untuk dapat menyerap, menghimpun, menampung dan menindaklanjuti aspirasi daerah pada implementasinya belum maksimal. Hal ini dikarenakan adanya kendala yang dihadapi. Pelaksanaan peran anggota Dewan Perwakilan Daerah Republik Indonesia (DPD RI) asal Jawa Tengah berkaitan dengan pembagian tugas masing-masing anggota. Pembagian tugas masing-masing anggota berkaitan dengan salah satu alat kelengkapan DPD yaitu Panitia Ad Hoc (PAH). Salah satu pelaksanaan peran anggota DPD RI asal Jawa Tengah dengan kunjungan kerja yang telah dilakukan pada tahun sidang 2004 2005 dan pada tahun sidang 2005- 2006. 
2. Penyerapan aspirasi daerah dilakukan dalam dua bentuk yaitu secara langsung dan tidak langsung. Tata cara penyerapan aspirasi melalui tahapan-tahapan tertentu.

3. Kendala-kendala yang dihadapi untuk meningkatkan peran anggota Dewan Perwakilan Daerah asal Jawa Tengah dalam rangka menyerap aspirasi daerah meliputi faktor internal dan faktor eksternal begitupula upaya-upaya untuk meminimalisir kendalakendala tersebut juga meliputi faktor internal dan eksternal.

\section{Saran}

1. Sebaiknya anggota Dewan Perwakilan Daerah Republik Indonesia asal Jawa Tengah dalam melaksanakan perannya tetap melakukan dengan maksimal sesuai peraturan yang ada meskipun masih terdapat kendala. Oleh karena itu yang lebih penting adalah bagaimana agar kepentingan dan kebutuhan masyarakat bisa terfasilitasi.

2. Seharusnya kelanjutan penyerapan aspirasi masyarakat tersebut dapat maksimal. Oleh karena itu diperlukan kesadaran masyarakat untuk ikut berpartisipasi.

3. Adanya kendala-kendala yang ada sebaiknya tidak dijadikan alasan untuk tidak tercapainya tujuan awal dibentuknya Dewan Perwakilan Daerah.

\section{DAFTAR PUSTAKA}

\section{$\underline{\text { Buku-buku }}$}


Ali, Faried, 1997, Hukum Tata Pemerintahan dan Proses Legislatif di Indonesia, Jakarta: Rajawali Press.

Al Marsudi H. Subandi, 2001, Pancasila dan UUD 1945 dalam Paradigma Reformasi, Jakarta: Raja Grafindo Persada.

Alrasyid, Harun, 2003, Naskah UUD 1945 Sesudah Empat Kali Diubah oleh MPR, Jakarta: UI-Press.

Amin, S.M., 1976, Demokrasi Selayang Pandang, Jakarta: Pradnya Paramita.

Amir, Makmur dan Reni Dwi Purnomowati, 2005, Lembaga Perwakilan Rakyat, Jakarta: Pusat Studi Hukum Tata Negara Fakultas Hukum Universitas Indonesia.

Ashshofa, Burhan, Metode Penelitian Hukum, (Jakarta: Rineka Cipta, 2004).

Asshiddiqie, Jimly, 2002, Konsolidasi Naskah UUD 1945 Setelah Perubahan Keempat, Jakarta: Pusat Studi Hukum Tata Negara FHUI.

------------------, 2005, Format Kelembagaan Negara dan Pergeseran Kekuasaan dalam UUD 1945, Yogyakarta: FH UII Press.

Asy'ari, Hasyim, Kedudukan dan Peran DPD dalam Sistem Ketatanegaraan Indonesia, Makalah dalam Semiloka "Optimalisasi Fungsi dan Kedudukan DPD RI secara Kelembagaan”, diselenggarakan di Semarang, 12 Januari 2006.

Azed, Abdul Bari, , 2001, Percikan tentang Hukum dan Demokrasi, Jakarta: Pusat Kajian Hukum Tata Negara FHUI.

Bahar, Saafroedin dan A.B Tangadililing, 1999, Integrasi Nasional: Teori, Masalah dan Strategi, Jakarta: Ghalia Indonesia.

Baldwin, Nicholas dan Shell Donald, 2001, Second Chambers, London: Frank Cass.

Budiarjo, Miriam, 2000, Dasar-Dasar Ilmu Politik, Jakarta: Gramedia Pustaka Utama. dan Ibrahim Ambong, 1993, Fungsi Legislatif dalam Sistem Politik Indonesia, Jakarta: Raja Grafindo.

Boboy, Max, 1994, DPR RI dalam Prespektif Sejarah dan Tata Negara, Jakarta: Pustaka Sinar Harapan.

C F. Strong, 2004, Konstitusi-Konstitusi Politik Modern, Bandung: Nusamedia.

Dewan Perwakilan Daerah Republik Indonesia, Kelompok DPD di MPR RI, 2006, Untuk Apa DPD RI, Jakarta: Kelompok DPD di MPR RI. 
Dewan Perwakilan Daerah Repiblik Indonesia dan Profil Anggota DPD RI 2004 - 2009, 2005, Jakarta: Sekretariat Jenderal MPR/DPD RI.

Dwipayan, Arie, 2000, Otonomi Versi Negara, Jakarta: Lapera Pustaka Utama.

Fajar, Mukthie, 2003, Reformasi Konstitusi dalam Masa Transisi Paradigmatik, Malang: In-Trans.

Gaffar, Afan, 1999, Politik Indonesia: Transisi menuju Demokrasi, Yogyakarta: Pustaka Pelajar.

Hamid, Edy Suandi dan Sobirin Malian, 2005, Memperkokoh Otonomi Daerah: Kebijakan, Evaluasi dan Saran, Yogyakarta: UII Press.

Hariono, 1992, Pemerintahan Lokal dari Masa ke Masa, Yogyakarta: Liberty.

Hatta, Muhammad, 2002, Kumpulan Pidato III, Jakarta: Gunung Agung.

Huda, Ni"matul, 2003, Politik Ketatanegaraan Idonesia: Kajian terhadap Dinamika Perubahan UUD 1945, Yogyakarta: FH UII Press.

Huijbers, Theo, 1995, Filsafat Hukum, Yogyakarta: Kanisius.

Ibrahim, Harmaily, 1979, MPR suatu Tinjauan dari Sudut Hukum Tata Negara, Jakarta: Sinar Bakti.

Ismael, Basuki, 1993, Paham Negara Telaah Filosofis atas John Locke, Jakarta: Intermedia.

Joeniarto, 1990, Sejarah Ketatanegaraan Republik Indonesia, Jakarta: Bumi aksara.

Kaelan, M.S. , 2000 ,Pendidikan Pancasila, Yogyakarta: Paradigma.

Kamus Besar Bahasa Indonesia, 2002, Jakarta: Balai Pustaka.

Kaho, Josef Riwu, 2002, Mencari Bentuk Otonomi Daerah, Jakarta: Rineka Cipta.

Karim, M.Rusli, 1991,Pemilu Demokratis Kompetitif, Yogyakarta: Tiara Wacana Yogya.

Kartaprawira, Rusadi, 1999, Sistem Politik Indonesia, Bandung: Sinar Baru Algensindo.

Kusnardi, Mohammad dan Harmaily Ibrahim, 1983, Pengantar Hukum Tata Negara Indonesia, Jakarta: Pusat Studi Hukum Tata Negara Fakultas Hukum Universitas Indonesia.

Kusnardi, Mohammad dan Bintan Saragih, 1978, Susunan Pembagian Kekuasaan menurut Sistem UUD 1945, Jakarta: Gramedia Pustaka Utama.

K. C. Where, 2003, Konstitusi-Konstitusi Modern, Surabaya: Pustaka Eureka. 
Lotulung, Paus Effendi, 1994, Himpunan Makalah Asas-Asas Umum Pemerintahan yang Baik, Bandung: Aditya Bakti.

Madjid, Nurcholis, 2004, Indonesia Kita, Jakarta:Universitas Paramadina.

Mahendra, Yusril Ihza, 1996, Dinamika Tatanegara Indonesia, Jakarta: Gema Insani.

Mahfud, MD, 1998, Politik Hukum Indonesia, Yakarta: LP3ES Indonesia.

Manan, Bagir, 2003, DPR, DPD dan MPR dalam UUD 1945 Baru, Yogyakarta: FH UII Press.

Bandung: Mandar Maju.

Maruto, M.D. dan Anwari MWK, 2002, Reformasi Politik dan Kekuatan Masyaraka, Kendala dan Peluang menuju Demokrasi, Jakarta: LP3ES.

Mas'oed, Mochtar, 2002, Politik, Birokrasi dan Pembangunan, Yogyakarta: Pustaka Relajar.

Mochtar, Hilmy, 2005, Politik Lokal dan Pembangunan, Yogyakarta: Pustaka Relajar.

Mubyarto, S., 2000, Otonomi dan Federalisme, Jakarta: Pustaka Sinar Harapan.

Naja, Daeng, 2004, Dewan Perwakilan Daerah, Bikameral Setengah Hati, Yogyakarta: Media Pressindo.

Napitupulu, Paimin, 2005, Peran dan Pertanggungjawaban DPR, Kajian di DPRD Propinsi DKI Jakarta, Bandung: Alumni.

Ndraha, Taliziduhu, 2003, Kybernolog, Ilmu Pemerintahan Baru, Jakarta: Rineka Cipta.

Nurtjahjo, Hendra, Perwakilan Golongan di Indonesia, Jakarta: Pusat Studi Hukum Tata Negara FHUI.

Oha, Miftah, 2003, Birokrasi dan Politik di Indonesia, Jakarta: Raja Grafindo Persada.

Perkembangan Kegiatan Alat Kelengkapan DPD RI (Buku I), Jakarta , 2005.

Prodjodikoro, Wirjono, 1989, Asas-Asas Hukum Tata Negara di Indonesia, Jakarta: Dian Rakyat.

Sagala, Budiman B. , 1982, Tugas dan Wewenang MPR di Indonesia, Jakarta: Ghalia Indonesia.

Soebagio, 1976, Aneka Masalah Hukum Tata Negara RI, Bandung: Alumni.

Soehino, 1993, Ilmu Negara, Yogyakarta: Liberty.

----------, 1981, Hukum Tata Negara, Teknik Perundang-Undangan, Yogyakarta: Liberty. 
Soekanto, Soerjono dan Sri Mamudji, 1995, Penelitian Hukum Normatif: Statu Tinjauan Singkat, Jakarta: Raja Grafindo.

Soemantri, Sri, 1973, Tentang Lembaga-Lembaga Negara menurut UUD 1945, Bandung: Alumni.

Sudharto, Kedudukan dan Peran DPD dalam Sistem Ketatanegaraan Indonesia, Makalah dalam Semiloka "Optimalisasi Fungsi dan Kedudukan DPD RI secara Kelembagaan”, diselenggarakan di Semarang, 12 Januari 2006.

Sunarno, Siswanto, 2006, Hukum Pemerintahan Daerah di Indonesia, Jakarta: Sinar Grafika.

Sunggono, Bambang, 1994, Hukum dan Kebijakan Publik, Jakarta: Sinar Grafika.

Suny, Ismail, 1978, Mekanisme Demokrasi Pancasila, Jakarta: Aksara Baru.

Surbakti, Ramlan, 1997, Reformasi Kekuasaan, Jakarta: Grasindo.

Suseno, Frans Magnis, 1997, Mencari Sosok Demokrasi, Jakarta: Gramedia Pustaka Utama. Pustaka Utama.

Syafiie, Inu Kencana, 1993, Sistem Pemerintahan Indonesia, Jakarta: Rineka Cipta.

Wahab, Solichin Abdul, 1997, Analisis Kebijaksanaan, Jakarta: Bumi Aksara.

Wiko, Garuda, 2006, Hukum dan Politik di Era Reformasi, Surabaya: Srikandi.

Tambunan, ASS, 1991, MPR Perkembangan dan Pertumbuhan: Suatu Pengamatan dan Analisis, Jakarta: Sinar Harapan.

Thaib, Dahlan, 1998, Implementasi Sistem Ketatanegaraan menurut UUD 1945, Yogyakarta: Liberty.

Tutik, Titik Triwulan, 2006, Pokok-Pokok Hukum Tata Negara Indonesia, Jakarta: Prestasi Pustaka.

Peraturan perundang-undangan

Undang-Undang Dasar Negara Republik Indonesia Tahun 1945.

TAP MPR No. IX/ MPR/ 2000 Tentang Penugasan Badan Pekerja MPR RI untuk mempersiapkan Rancangan Perubahan UUD Negara Republik Indonesia Tahun 1945.

Undang-Undang Nomor 22 Tahun 2003 Tentang Susunan dan Kedudukan Dewan Perwakilan Rakyat, Dewan Perwakilan Daerah dan Dewan Perwakilan Rakyat Daerah. 
Undang-Undang Nomor 32 Tahun 2004 Tentang Pemerintahan Daerah.

Undang-Undang Nomor 10 Tahun 2004 tentang Pembentukan Peraturan Perundangundangan.

Keputusan Presiden No 157 tahun 2000 tentang Pengangkatan anggota DPD RI.

Peraturan Presiden RI Nomor 51 Tahun 2005 tentang Sekretariat Jenderal DPD RI.

Peraturan Tata Tertib Dewan Perwakilan Daerah Republik Indonesia Tahun 2005.

Peraturan tentang Kode Etik Dewan Perwakilan Daerah Republik Indonesia.

$\underline{\text { Surat Kabar }}$

Arinantyo, Satya, Setelah MPR menjadi ”Bikameral” dari Kompas, 9 Agustus 2002.

Hariyadi, Agus, Bikameral Setengah Hati dari Kompas, 15 Mei 2002.

Hubungan Lembaga Negara: DPD merasa DPR Tak Indahkan Kehadirannya dari Kompas, 15 Juli 2005.

Prasojo, Eko, Pemilihan Anggota DPD dalam RUU Susunan dan Kedudukan dari Kompas, 11 Agustus 2003.

Purnomowati, Reni Dwi, Menyoal Anggota DPD dari Kompas 5 Januari 2004.

DPD Kirim Surat Ke Menakertrans, Banyak Perusahaan Tak Ikut Jamsostek dari Suara Merdeka, 28 Februari 2005.

DAU Dikeluhkan ke Anggota DPD dari Suara Merdeka, 8 April 2005.

Wonogiri Diusulkan Jadi Dua Kabupaten dari Suara Merdeka, 15 April 2005.

Dari DAU sampai Pendidikan dari dari Suara Merdeka, 20 Juli 2005.

DPD Undang Menteri Pan Bahas Pengangkatan Guru Honorer dari Suara Merdeka, 1 Februari 2006.

Internet

http://www.dpd.go.id

http://www.hukumonline.com 